\title{
PHYSICAL FUNCTIONING OF CHILDREN/ADOLESCENTS WHO HAVE COMPLETED ACUTE LYMPHOBLASTIC LEUKEMIA TREATMENT
}

\author{
FUNKCJONOWANIE FIZYCZNE DZIECI/MŁODZIEŻY \\ PO ZAKOŃCZENIU LECZENIA OSTREJ BIAŁACZKI LIMFOBLASTYCZNEJ
}

Department of Paediatric Nursing, Collegium Medicum in Bydgoszcz, Nicolaus Copernicus University in Toruń

S u m m a r y

The purpose of this paper is to evaluate the quality of life of children who have completed ALL treatment with respect to physical functioning as compared to healthy children of similar age.

Materials and methods. The research was conducted among patients treated in the Chair and Clinic of Pediatrics, Hematology and Oncology of Nicolaus Copernicus University Collegium Medicum in Bydgoszcz, who completed acute lymphoblastic leukemia treatment. It comprised children whose ALL treatment had finished at least 6 months prior to the research. The final group of patients who participated in the research consisted of 64 persons. Research referring to healthy children was carried out among students of primary schools, junior high schools and kindergartens throughout Bydgoszcz. Only children who had never undergone hospital treatment and did not suffer from chronic diseases were qualified for the said research. The comparative group included 70 healthy children. In order to evaluate the quality of life of children who had undergone ALL treatment and of healthy children James W. Varni's standardized research instrument was used.

Results. As far as children's/adolescents' subjective opinion is concerned, physical functioning was evaluated the lowest by adolescents aged 13-18. Pain and fatigue have a significant influence on lowering their quality of physical functioning. The highest evaluation of physical functioning was observed among patients aged 5-7. As far as indirect evaluation is concerned one can notice that physical functioning was evaluated the lowest by parents of children aged 13-18 and 2-4. While comparing physical functioning in both research groups major statistical differences in favour of the comparative group were noticed.

C on clus i on. The quality of life within the sphere of physical functioning of children and adolescents who have completed treatment is significantly lower than among healthy children.

\section{Streszczenie}

Celem pracy jest ocena jakości życia w sferze funkcjonowania fizycznego dzieci po zakończonym leczeniu ALL na tle zdrowej populacji w podobnym wieku.

Materiał i metody. Badania przeprowadzono wśród pacjentów leczonych w Katedrze i Klinice Pediatrii, Hematologii i Onkologii Collegium Medicum Uniwersytetu Mikołaja Kopernika w Bydgoszczy, którzy zakończyli leczenie ostrej białaczki limfoblastycznej. Badaniami objęto dzieci, które zakończyły leczenie ALL przynajmniej 6 miesięcy przed badaniem. Ostateczna liczba osób, biorących udział w badaniu wynosiła 64.Badania wśród dzieci zdrowych przeprowadzono wśród uczniów szkoły podstawowej, gimnazjum oraz przedszkola na terenie
Bydgoszczy. Do badania zakwalifikowano dzieci, które nigdy nie były poddane leczeniu szpitalnemu oraz nie chorują na choroby przewlekłe. Grupę porównawczą stanowiło 70 dzieci zdrowych.Do oceny jakości życia dzieci po zakończonym leczeniu ALL oraz dzieci zdrowych użyto standaryzowanego narzędzia badawczego autorstwa Jamesa W. Varni.

Wyniki. Funkcjonowanie fizycznew subiektywnym odczuciu dzieci/ młodzieży najniżej ocenione było przez grupę młodzieży w wieku od 13 do 18 lat. Istotny wpływ na obniżenie jakości funkcjonowania fizycznego ma $\mathrm{u}$ nich odczuwanie bólu oraz zmęczenia.Najwyżej oceniali funkcjonowanie fizyczne pacjenci w grupie 5-7 lat.W ocenie 
pośredniej najniższą wartość punktową funkcjonowania fizycznego uzyskano w grupie rodziców dzieci w wieku 1318 lat oraz 2-4 lat. Porównując funkcjonowanie fizyczne w obu badanych grupach zauważono istotne statystycznie różnice na korzyść grupy porównawczej.
W niosek. Jakość życia w sferze funkcjonowania fizycznego dzieci i młodzieży po zakończonym leczeniu jest znamiennie niższa niż wśród dzieci zdrowych.

Key words: quality of life, acute lymphoblastic leukemia, physical functioning

Stowa kluczowe: jakość życia, ostra białaczka limfoblastyczna, funkcjonowanie fizyczne

\section{INTRODUCTION}

There are 105-130 cases of childhood neoplastic diseases per 1 million children noted every year. They are the second most common death cause among children with only injuries and poisonings being more frequent. There are approximately 1,100-1,300 new cases diagnosed in Poland every year [1, 2, 3]. Prevalence of neoplastic diseases differs in Poland, Europe and the USA; however, the most frequently observed type of childhood neoplastic diseases is acute lymphoblastic leukemia.

Until recently the main purpose of medicine was prolongation of sick persons' lives. Life prolongation was treated as a criterion for health care improvement and the so-called survival rate was an indicator of treatment success. Nevertheless, when success was achieved it turned out that life span is an insufficient measure of physicians' struggle for a patient's life. Saving a patient's life condemned him/her on numerous occasions to many years of vegetation. Such a patient had to be taken care of by the loved ones and was dependent on them. As a result, research concentrated not only on saving lives, but also on ways to make them happy ones $[4,5,6]$.

The quality of life is a subject of interest in medicine, psychology, sociology and other sciences. There are four basic elements which constitute a patient's quality of life: the somatic condition, mental health, social relations and physical fitness. The notion of Health-Related Quality of Life (HRQL) was introduced in 1990 by Shipper. According to its definition, quality of life is 'a functional effect of a disease and the consequences of its treatment from a patient's point of view' $[5,7,8]$. HRQL consists of four spheres:

1. physical sphere - evaluation of basic physiological functions' efficiency, activity level described by an ability to perform self-care activities, performance of physical work, mental work, recreation;

2. mental sphere - level of disease adjustment, existence (or non-existence) of negative feelings, i.e. fear, rage, depression, and positive feelings, i.e. happiness, joy, hope;

3. social sphere - type and quality of interpersonal relations, ability and willingness to undertake social activity;

4. somatic sensations sphere - symptoms which can be observed in a patient's everyday life and their influence on the patient's quality of life [9- 12].

In medicine quality of life is connected not only with the objective dimension, but also with the subjective one [13]. According to $H$. Kunsebeck subjective components of life quality include:

- physical determinants (ailments, pain, physical health),

- mental determinants (hope, anxiety, depression, dignity),

- social determinants (satisfaction from work, way of spending free time),

- interpersonal determinants (social support, conflicts with partners, interpersonal relations).

Objective components of life quality include:

- health condition evaluated on the basis of laboratory tests,

- a diagnosis connected with psychopathology,

- social-economic status (income, housing conditions, conditions at work, amount and quality of contact with the surroundings, place in the social structure).

The objective determinants of life quality are connected with the clinical concept of a disease which does not always comply with a patient's perception of his/her health state $[4,13,14]$.

Evaluation of the quality of life is a part of a complete clinical evaluation of a patient. It has a special meaning with respect to chronic diseases which can have a negative influence on a patient's life, his/her physical, mental, social, family and occupational functioning. Consequently, evaluation of the quality of life of children who have completed acute lymphoblastic leukemia treatment is of great importance. It often becomes a manifestation of the success of treatment. 


\section{MATERIALS AND METHODS}

The research was conducted among patients treated in the Chair and Clinic of Pediatrics, Hematology and Oncology of Nicolaus Copernicus University Collegium Medicum in Bydgoszcz, who completed acute lymphoblastic leukemia treatment. The research made use of a diagnostic questionnaire which was mailed to be filled out by a patient and his/her parents. In order to participate in the research a written consent had to be expressed.

The research was carried out once the Commission of Bioethics of Nicolaus Copernicus University in Torun at the Ludwig Rydygier Collegium Medicum in Bydgoszcz granted its consent (no.: KB/666/2005).

The research comprised children whose ALL treatment had finished at least 6 months prior to the research. The final group of patients who participated in the research consisted of 64 persons. The number of boys and girls was comparable and amounted to 33 and 31 , respectively. The average age of children at the moment of research was 11.3 (scope: 4-18 years old, median - 11) and at the moment of diagnosis 6 (scope: 1-17 years old, median - 5).

Research referring to healthy children was carried out among students of primary schools, junior high schools and kindergartens throughout Bydgoszcz. Only children who had never undergone hospital treatment and did not suffer from chronic diseases were qualified for the said research. The comparative group included 70 healthy children: 31 girls and 39 boys. The children were aged from 2 to 17 , with the average age of 10.98 (median -12). The most numerous group consisted of children aged 8-12 $(\mathrm{n}=58)$.

In order to evaluate the quality of life of children who have undergone ALL treatment and of healthy children, James W. Varni's standardized research instrument was used [15-20]. Permission to use the questionnaire was granted by the Mapi Research Trust Institute in Lyon. The respondents were giving answers according to a five-item scale by choosing one out of five answers. Evaluation of particular aspects of functioning took place by answering how often a child has problems with aspects of everyday life mentioned in the questionnaire. All answers were assigned points: $0=100$ pts, $1=75$ pts, $2=50$ pts, $3=25$ pts, $4=0$ pts. The scores obtained through particular scales as well as the final score were calculated as an arithmetic mean presented as points from 0-100. The higher the calculated value, the better the quality of life.

\section{RESULTS}

As far as children's/adolescents' subjective opinion is concerned, physical functioning (Fig. 1) was evaluated the lowest by adolescents aged 13-18. Pain and fatigue have a significant influence on lowering their quality of physical functioning. Similar results can be observed among children aged 8-12. The total amount of points in that age group equals 83.35. The highest evaluation of physical functioning was observed among patients aged 5-7. Pain was a factor which lowered this group's evaluation. Walking (96.19) and taking a bath without other person's help (95.76) were the least troublesome aspects of physical functioning in all age groups.

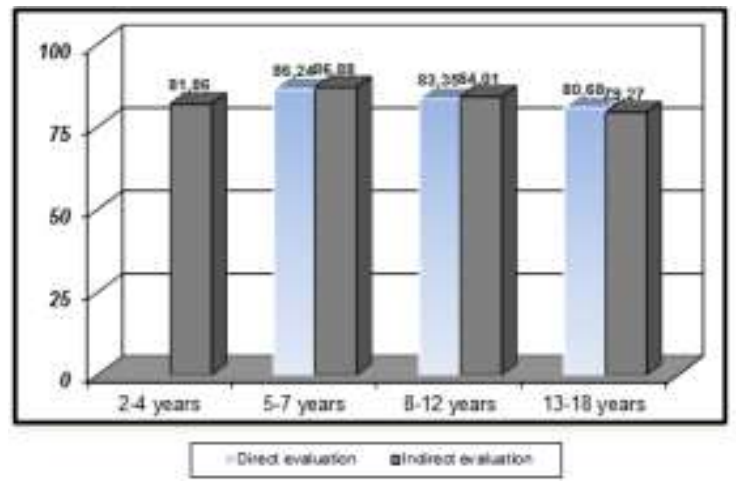

Fig. 1. Physical functioning in different age groups

As far as indirect evaluation is concerned, it was observed that the lowest evaluation of physical functioning (Fig. 1) pertained to parents of children aged 13-18 (79.27) and 2-4 (81.86). The aspect which, according to parents, lowers children's/adolescents' physical functioning is pain and with respect to the older age group - also fatigue. Parents of children aged 2-4 noticed that the most problematic action for their children is helping with chores (collecting one's own toys).

While comparing physical functioning in both research groups (Fig. 2) major statistical differences in favour of the comparative group were noticed. As far as direct evaluation is concerned they pertained to running (79.66 vs. 92.06; $\mathrm{p}=0.002$ ), active participation in games/sports (79.66 vs. $93.25 ; \mathrm{p}=0.001)$ and chores that involved cleaning ( 83.05 vs. $90.87 ; p=0.036$ ).

Physical functioning evaluation performed by parents of children from both groups (Fig. 2) shows that the most prominent differences, in favour of healthy children, concerned running ( 85.16 vs. 92.50 ; $\mathrm{p}=0.027)$, active participation in games/sports $(83.59$ 
vs. 91.43; $\mathrm{p}=0.043$ ), lifting heavy objects (77.73 vs. $85.71 ; \mathrm{p}=0.043)$ and experiencing pain (66.02 vs. $75.71 ; \mathrm{p}=0.019)$.

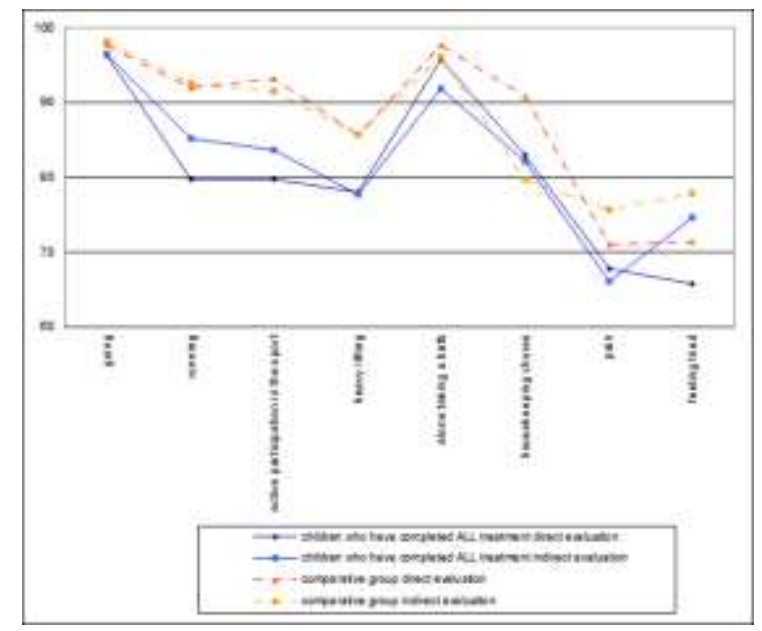

Fig. 2. Children's/adolescents' physical functioning according to direct and indirect evaluation

General evaluation of physical functioning among children who had completed oncological treatment (Fig. 3) was notably lower than evaluation among healthy children not only when it comes to direct evaluation ( 82.42 vs. 87.36 ; $\mathrm{p}=0.024)$, but also with respect to indirect evaluation (82.14 vs. 86.98; $\mathrm{p}=0.049$ ).

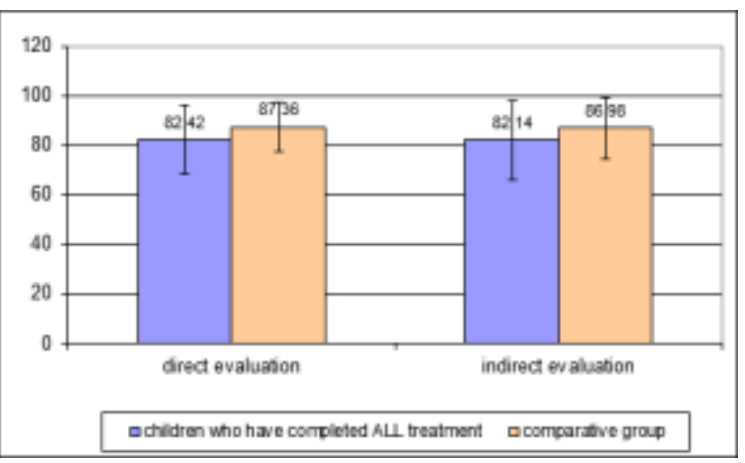

Fig. 3. Average evaluation of physical functioning within groups covered by the research

\section{DISCUSSION}

Zdebska S. and Armata J. devoted many articles [21-31] to psychological and social-educational issues connected with treating children suffering from haematological malignancies. The authors emphasised that cooperation of scientific workers employed in clinics and research facilities does not only improve methods of treatment, but also lets one carry out tests which can contribute to a child's/adolescent's biopsycho-social well-being. The above conclusion became an inspiration for own research dealing with the quality of life after completing acute lymphoblastic leukemia treatment.

Children who had completed ALL treatment evaluated their physical functioning (82.42) lower than healthy children (87.36). Statistically significant differences pertained to running (79.66 vs. 92.06), active participation in games/sports (79.66 vs. 93.25) and chores that involved cleaning (83.05 vs. 90.87). The lowest evaluation of the first two aspects was performed by adolescents aged 13-18 (73.08; 76.92). Chores, on the other hand, received the lowest evaluation from children aged 8-12 (79.46). Children between 5 and 7 years old evaluated their physical functioning the highest (86.24).

In E. Mess' research children who had completed ALL treatment evaluated their physical activity on a three-level scale (low, average, high). $86.2 \%$ of children from the research group $(n=29)$ evaluated their physical activity as average or high. Evaluation was conditioned by the number of somatic ailments. The more post-treatment complications, the lower the evaluation of physical functioning was. What is more, the evaluation was connected with low self-esteem and stronger expression of negative emotions [32].

In materials by Meeske, $\mathrm{K}$. et al. children/adolescents who had completed ALL treatment complained of chronic fatigue which often coexisted with depression (30\%) [33].

During the research carried out in Los Angeles and San Diego, parents of children who had completed ALL treatment evaluated their children's physical functioning lower than in the own research (71.65 vs. 82.14). The evaluation differed for children who had completed treatment <12 months and > 12 months before the research (65.4 vs. 77.9) [15].

As far as own research is concerned, it has been demonstrated that there is a connection between the time that passed from treatment completion and direct evaluation of functioning in the physical sphere. The more time passes from oncological treatment completion, the lower the results of an evaluation of physical functioning are. The above situation might be influenced by occurrence of late complications of oncological treatment, which might limit former patients' physical fitness. The own research was not aimed at evaluating complications occurring after treatment. Consequently, it is impossible to draw binding conclusions in this matter. However, the obtained results indicate a necessity for further 
research that would answer the following question: why does functioning in the physical sphere decrease as the time from treatment completion goes by?

Acute lymphoblastic leukemia and the way of treating it have a negative influence on the emotional development, physical, social and school-related functioning of children who finished treatment. A child who has undergone oncological treatment struggles against many problems which very often surpass a child's ability to solve them on his/her own.

'Well follow-up' clinics offering comprehensive care and rehabilitation are created all over the world with a group of children called by J. Armata 'convalescents' (cancer survivors) in mind.

Care provided to a child that has been cured from a neoplastic disease should include not only early diagnosis and treatment of complications resulting from oncological treatment, but it should also help the child to adjust himself/herself to 'normal' life. It is advisable to create and introduce to oncological procedures programs that would provide care to patients and which would include observations of all spheres of life that constitute an evaluation of its quality. The entire therapeutic team's work should concentrate on making a young persons life primarily the same as the life of his/her peers regardless of troublesome experiences caused by treatment.

\section{REFERENCES}

1. Dangel T., Szamotulska K., Wojciechowska U., Zapotrzebowanie na opiekę paliatywną nad dziećmi w Polsce - analiza epidemiologiczna, Pediatria Polska 2000, LXXV, 9: 695-707

2. Kowalczyk J., Dudkiewicz E., Balwierz W., wsp. Incidence of childhood cancers in Poland in 1995-1999, Med Sci Monit 2002; 8(8): CR587-590

3. Mielniczuk H., Borkowski W. Rejestracja nowotworów dziecięcych w Polsce, Med Wieku Rozw. 2003, 7: 315 324

4. Kowalik s., Ratajska A., Szmaus A. W poszukiwaniu nowego wymiaru jakości życia związanego ze stanem zdrowia, [w:] Wołowicka Laura, Jakość życia w naukach medycznych, Poznań 2001: 17-29

5. Książek J., Piotrkowska R., Gaworska- Krzemińska A. Ocena jakości życia pacjentów w teorii i praktyce pielęgniarskiej, Pielęgniarka i Położna 2005, 4: 25-26

6. Łaszczewska V. Jakość życia pacjentów $\mathrm{z}$ chorobą nowotworową, Przegląd Urologiczny 2002 (2): 74-77

7. Mazur J., Mierzejewska E. Health-related quality of life (HRQL) in children and adolescents - concepts, study methods and selected applications, Med. Wieku Rozw. 2003, nr. 1, cz. II, styczeń - marzec, tom VII : 36-48
8. Shipper H. Quality of life: principles of the clinical paradigm. J. Psychosoc Oncol 1990; 8: 171-185

9. de Walden - Gałuszko K. Jakość życia - rozważania ogólne [w:] Walden - Gałuszko K., Majkowicz M., Jakość życia w chorobie nowotworowej, Gdańsk 1994: 13-39

10. de Walden - Gałuszko K., Majkowicz M. Ocena jakości opieki paliatywnej w teorii i praktyce. Gdańsk AM 2000

11. Stelcer B. Psychologiczny wymiar pojęcia jakość życia, Postępy Pielęgniarstwa i Promocji Zdrowia, cz. XI pod redakcją prof. dr hab. Laury Wołowickiej, Poznań 1997, Akademia Medyczna im. K. Marcinkowskiego w Poznaniu: 156-160

12. Szkultecka-Dębek M., Mazur J. Jakość życia związana ze zdrowiem - metody pomiaru, Farmakoekonomika 2005, 9 (3): 3-20

13. Tobiasz-Adamczyk B. Wybrane elementy socjologii zdrowia i choroby, Wydawnictwo Uniwersytetu Jagiellońskiego, Kraków 2000: 233-251

14. Parnowski T. Jakość życia- refleksje. Medycyna po Dyplomie 2008; vol.17, 4: 52-53

15. Meeske K., Katz E., Palmer S., Burwinkle T., Varni J. Parent Proxy-Reported Health- Related Quality of Life and Fatigue in Pediatric Patients Diagnosed with Brain Tumors and Acute Lymphoblastic Leukemia, Cancer 2004, 101: 2116-2125

16. Varni J.W., Burwinkle T.M., Seid M. The PedsQL TM 4.0 as a school population health measure: Feasibility, reliability and validity. Quality of Life Research 2006, 15: 203-215

17. Varni J.W., Limbers Ch.A., Burwinkle T.M. Impaired health- related quality of life in children and adolescents with chronic conditions: a comparative analysis of 10 disease cluster and 33 disease categories/ severities utilizing the PedsQL TM 4.0 Generic Core Scales. Health and Quality of Life Outcomes 2007, 5: 43-58

18. Varni JW, Burwinkle TM, Seid M, Skarr D. The PedsQL 4.0 as a pediatric population health measure: Feasibility, reliability and validity. Ambul Pediatr 2003; 3: 329-341

19. Varni JW, Burwinkle TM, Seid M. The PedsQL 4.0 as school population health measure: Feasibility, reliability and validity. Quality of Life Research 2006; 15: 203215

20. Varni, JW, Burwinkle TM, Katz ER et al. The PedsQL ${ }^{\mathrm{TM}}$ in pediatric cancer: Reliability and validity of the Pediatric Quality of Life Inventory ${ }^{\mathrm{TM}}$ Generic Core Scales, Multidimensional Fatigue Scale, and Cancer Module. Cancer 1994: 2090-2106

21. Zdebska S., Armata J., Balwierz W., wsp. Ocena i perspektywy psychosocjalnej adaptacji dziecka $\mathrm{Z}$ chorobą nowotworową, Ped. Pol. 1991, LXVI, 9-10: $132-136$

22. Zdebska S., Armata J., Balwierz W. Wyniki kontrolnych badań psychologicznych testem Wechslera leczonych z powodu nowotworowych chorób krwi, Ped. Pol., 1987, 62, 7: 490-498 
23. Zdebska S., Armata J. Niektóre problemy psychologiczno-wychowawcze w opiece nad dzieckiem szkolnym z nowotworową chorobą krwi, Ped. Pol., 1979, 54, Nr 8: 919- 924

24. Zdebska S., Armata J. Percepcja choroby i leczenia u starszych dzieci chorych na nowotwory krwi, Ped. Pol., 1981, 56: 969-973

25. Zdebska S., Armata J. Pojęcie i lęk śmierci u dzieci w świetle ich wypowiedzi, Ped. Pol., 1983, 58: 63-69

26. Zdebska S., Armata J. Społeczno-moralne dojrzewanie dzieci leczonych $\mathrm{z}$ powodu nowotworowych chorób krwi, Ped. Pol., 1982, 57: 855-859

27. Zdebska S., Armata J. Udział dziecka i jego zadania w leczeniu nowotworowej choroby krwi, ped. Pol., 1979 54: 911-914

28. Zdebska S., Armata J. Udział lekarza we współpracy z chorym dzieckiem i jego rodziną podczas leczenia nowotworowej choroby krwi, Ped. Pol., 1985, 40: 45-49

29. Zdebska S., Armata J. Udział rodziców w leczeniu ich dziecka z chorobą nowotworową, Ped. Pol., 1978, 53: 621-627

30. Zdebska S., Balwierz W., Rytlewska M., Armata J. Stan rozwoju umysłowego dzieci leczonych $\mathrm{z}$ powodu nowotworowych chorób krwi, Ped. Pol., 1982, 57: 391397
31. Zdebska S. Losy dzieci $\mathrm{z}$ wieloletnią remisją $\mathrm{w}$ nowotworach układu limfatycznego. Okres obserwacji 6-15 lat. Ped. Pol. 1985, 60: 361-367

32. Mess E. Ocena stanu psychicznego dzieci leczonych $z$ powodu ostrej białaczki limfoblastycznej, Polska Medycyna Paliatywna 2002, tom 1, nr 2: 9-21

33. Meeske K., Siegel S.E., Globe D.R., Mack W.J., Bernstein L. Prevalence and correlates of fatigue in long-term survivors of childhood leukemia. J Clin Oncol 2005, 23(24): 5501-5510

\section{Address for correspondence:}

\author{
Aneta Zreda-Pikies \\ ul. Techników 3 \\ 85-801 Bydgoszcz \\ e-mail: aneta.zreda@wp.pl
}

Received: 15.10.2014

Accepted for publication: 10.03.2015 